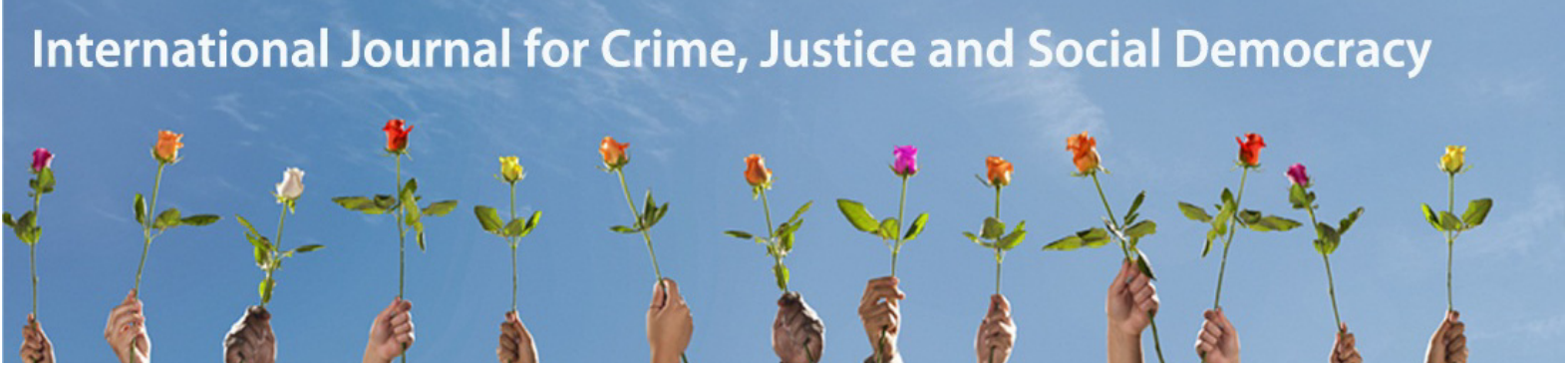

\title{
The Revival of Comparative Criminology in a Globalised World: Local Variances and Indigenous Over-representation
}

\author{
Hilde Tubex ${ }^{1}$ \\ University of Western Australia
}

\begin{abstract}
In this article, I first examine the viability of comparative criminological research in a globalised world. Further, I test the validity of some global explanatory models against the local situation in countries that appear to resist the dominant trend, such as the Netherlands and Canada. I then zoom in even further to the intra-national differences in some federal nations, such as Canada and Australia, where this situation is often linked to the overrepresentation of Indigenous people and the consequences of colonialism. Finally, I discuss the future of comparative criminological research.
\end{abstract}

\section{Keywords}

Punitiveness, welfare, neoliberalism, colonialism, Indigenous / Aboriginal.

\section{Introduction}

I argued in a previous article (Tubex 2013), that comparative criminology is a rather young discipline, as crime and justice were not hot topics in the optimistic, generous and positive decades following the Second World War. However, the global economic crisis of the seventies, the subsequent decline of belief in the penal welfare state, and the increase in crime rates and prison populations dramatically changed this picture. Criminologists started to look across borders in an attempt to understand the causes of increasing prison populations. David Garland's pioneering Culture of Control (2001) set the benchmark for an understanding of the recent trends in penal policy. Partly as a reaction to his work, comparative criminologists have produced a wealth of information and evidence over the last two decades, providing insight into what is impacting on prison populations and explaining different levels of punitiveness. Therefore, it is timely to critically examine the extent to which the current evidence is capable of explaining convergences and divergences in penal practice. To make international comparison possible, I use imprisonment rates $^{2}$ as a measure for punitiveness, while remaining highly aware of the limitations of using this tool.

Before doing this, I first question the viability of comparative research in a globalised world, as levels of punitiveness are increasingly linked to global processes. It becomes apparent, however, that there is great diversity in the way countries have been responding to global trends and, 
even within countries, there are significant regional differences. I argue that, despite the impressive output of comparative criminology over recent years, it is still an ongoing struggle to understand what is driving penal policies and practices, and that new directions might be needed.

\section{The sense of comparative research in a globalised world}

The impact of globalisation on crime and criminal justice is an important consideration from the perspective of comparative research. One reason for this is the link between globalisation and punitiveness, the main point of interest of comparative criminology. Baker and Roberts (2005) point to the various reasons why 'new punitiveness' is associated with globalisation. They argue, however, that globalisation does not necessarily cause punitiveness, as it is not a universal trend. Globalisation is a complex phenomenon, which has definitely affected penal policies, privileging punitive responses and facilitating 'policy transfer', but it can as well 'spark diverse, jurisdiction-specific responses' (Baker and Roberts 2005: 122).

A further reason is the fact that globalisation, of itself, presents specific challenges to the credibility of nation states: as crime increasingly displays international dimensions, it is becoming more and more difficult for nation states to deal with it. Globalists claim that a global criminology instead of comparative criminology is needed to understand what is happening in this field (Larsen and Smandych in Nelken 2011).

Comparative criminologists have defended their discipline, pointing to differences between countries due to local features, values and cultures. Further, it has been argued that, for every global model explaining levels of punitiveness, there are exceptions, as will be discussed later in this contribution. In addition, there is at the same time the contradictory process of glocalisation: the persistence of national and even regional autonomy in the face of global pressures (Meyer and O’Malley 2005). Globalisation doesn't spell convergence, according to Lacey (2011); therefore, comparative research on national and regional levels is crucial to understand the mechanisms by which master narratives affect penal policy in different ways, in different countries. Meaningful comparative research needs to move back and forth between the global and the local, refining the global model with local empirical data and findings, as features within individual countries might explain how and why they deviate from the leading pattern. Along the same lines, Savelsberg (2011) concludes that both the study of globalisation and cross-national comparative research are needed, and that they need to be closely linked, as global trends are translated in a nation-specific way and filtered through local institutions. Nelken (2011) agrees with this view, pleading that comparative research is particularly well placed to study the interaction between the global and local forces and the ways how to best do this. Therefore, and according to these authors, despite globalisation, comparative research still has a place within criminology, identifying local dynamics and ways out of the doom scenario of mass imprisonment (Lacey 2008).

\section{Global explanatory models in a local context}

To critically examine the explanatory power of the current evidence, I discuss in the following paragraphs two deep-rooted global models used to explain levels of punitiveness, and test their validity against the situation in two countries that seem to fall outside the general trend of ever increasing prison populations: the Netherlands and Canada.

\section{Welfare and punitiveness}

First, a well established and apparently solidly evidenced relationship is the one between welfare and punitiveness. Looking at the differences between imprisonment rates within the US, Beckett and Western (2001) find that states with higher investments in welfare and rehabilitation have lower imprisonment rates. They suggest these states are more inclusive, considering criminality as a societal problem that needs to be addressed with a social policy 
instead of a penal policy. In the more exclusionary states, crime is considered an individual responsibility that is met by punitiveness, so they have higher imprisonment rates. They also identify an overrepresentation of black Americans in these states, and the fact that this trend increases over time. The welfare hypothesis seems equally true for a sample of 18 OECD countries, where Downes and Hansen (2006) find a statistically significant negative relationship between the investment in welfare and imprisonment rates. Nevertheless, the welfare model as a protection against increasing prison rates only seemed to work in certain countries, such as Scandinavia. Others saw their prison populations going up while their welfare model was still in place. Downes (2011) points in this respect to the example of the Netherlands as being an anomaly, quintupling its prison population rate while retaining many of the features that should have protected it against penal excess, being a social democracy and a relatively substantial welfare state. Therefore, a closer look at the Dutch case is warranted.

The Netherlands as a case study

The Netherlands has always been a challenging country for criminological analysis, and may, therefore, provide a good subject through which to test the validity of explanatory models. For very many years the shining example of penal moderation, with imprisonment rates as low as 18 per 100,000 inhabitants in 1973, the Netherlands was about the only country that could keep pace with the US in the way its prison population multiplied (up to 134 per 100,000 in 2005). But even more interesting is the recent evolution and the fact that the prison population has been on the decrease since 2005 (down to 87 per 100,000 in 2011) (van Swaaningen 2013). The explanations given for this rather remarkable trend are diverse and contradictory.

According to van Dijk (2011), it has all to do with the registration of crime and developments in the crime pattern. Using correct data and similar definitions as other countries do, the Dutch fluctuations would have been a lot less distinctive: they were initially deflated by the exclusion of mentally ill convicts held in private clinics, and later inflated by the inclusion of illegal immigrants held in administrative detention centres and juveniles placed in institutions as a civil protection measure. After adjusting for these two, the imprisonment rate in 2007 would decrease by 30 per cent - from 113 to 72 - far below the European mean of 119. Further, he claims - relying on data from the International Crime Victims Survey - that the growing / declining imprisonment rates are much more closely related to changes in (serious) crime instead of changes in punitiveness.

This claim is partly confirmed in the study of Vollaard and Moolenaar (2009), who also attribute the increase in the prison population to an increase in drug and violence related cases brought before the judges. But, as Boone and Moerings (2007) indicate, this does not mean that these offences have increased as the number of cases sent to the prosecutor remains stable; it is the number that is sent to the courts that has increased and, as such, it is an expression of increased punitiveness. The decrease is, according to Vollaard and Moolenaar (2009), due to milder sentencing practices for drug offences and less serious violent acts, and a more frequent use of community based sentences. Van Dijk (2011) disagrees with the latter, as alternative sentencing in his view only had a marginal impact and milder sentences have more to do with an effective drop in the number of serious crimes instead of the judges' practices. Vollaard, Versteeg and van den Brakel (2009) confirm the drop in, particularly, property crimes and acts of violence, due to demographic and economic factors. However, they assert that, at the same time, there is a more stringent penal policy developing towards violence and, as a result of lower tolerance and changed police practice, less serious cases were being brought before the judges and therefore resulted in shorter sentences (Vollaard and Moolenaar 2009; Vollaard, Versteeg and van den Brakel 2009).

These signs of a growing punitiveness are confirmed by other authors (Boone and van Swaaningen 2012; van Swaaningen 2013). According to them, prison numbers increased because of a more punitive approach throughout the sentencing process (more reporting of 
crime, more people sent to court, also for less serious offences, more use of imprisonment and longer sentences). They see these changes as a result of the pressure of changing public opinion expressing less tolerance towards some minor forms of crime and towards vulnerable groups, minorities and people who are different in any way (mentally ill, juveniles and illegal immigrants) (Boone and Moerings 2007). The recent decrease in the imprisonment rate is due to a decrease in the use of imprisonment for property offenders and less use of remand. Further, there are also several policy initiatives that might have - even unintentionally - a decreasing effect. Concurrently, there is growing criticism of the punitive approach. Due to miscarriages of justice, the media are picking up on this trend and increasingly call in expert advice, and this is influencing the judiciary. In addition, crime is pushed down on the electoral agenda as other concerns, such as the economic crisis and healthcare, have become more important. However, as van Swaaningen (2013) points out, this does not mean that the Netherlands has become less punitive, as there are various examples of very punitive measures that have been introduced since 2005 such as a super-max prison (EBI); 'long stay' sections in psychiatric penitentiary clinics (TBS); increased maximum length of sentences; custodial sentences for breach of parole or diversion; three strikes laws (ISD); and anti-social behaviour orders. According to van Swaaningen (2013) it is not a matter of less punishment, but of different forms of punishment, along the lines of Foucault's 'penal-welfare complex', in which welfare provisions serve to discipline the population. Imprisonment has been replaced by other strategies of crime control, which are no less repressive than a prison sentence.

\section{Conclusion}

From this example it is clear how complex the explanation of prison populations can be, as perceived changes in crime can also be the result of changed police performance, prosecution practices and sentencing, which in their turn can be an expression of increased punitiveness. Using victim surveys can act as a corrector for this sort of analysis but perceptions of crime and victimhood can similarly affect reporting and signal decreasing tolerance. So it seems that, despite their welfare model still being in place, the Netherlands has lost some of its 'inclusionary' character over time. Decreasing tolerance towards some categories of crimes results in higher numbers of these offenders ending up in the criminal justice system. Failings of that system raise critical voices; nonetheless, it seems to expand in new forms of punishment, outside of prison, but still be a feature of a punitive society, despite the fact that the imprisonment rates are decreasing. After all, Lacey (2011) comments, welfare provisions are not solely the result of humanity: they are embedded in political and economical dynamics that are required for their ongoing support. This leads us to the second explanatory model.

\section{Neo-liberalism and punitiveness}

A second overarching theme that has gained rapid interest in criminological discourse is the relationship between neo-liberalism and punitiveness. As Brown (2011) indicates, this has been firmly put on the criminological agenda by Wacquant (2009) who identifies neo-liberalism as the root cause of punitivism, challenging the predominance of 'late modernity' in Garland's (2001) work. While Brown $(2011,2013)$ considers this approach a welcome contribution to the debate, he fears that Wacquant's interpretation of a specific form of neo-liberalism might overstate its impact. The theme has been picked up in recent work in comparative criminology, like the analysis of Cavadino and Dignan (2006) and Lacey (2008), bringing the impact of political economies back under the spotlight. Based on the study of 12 countries, Cavadino and Dignan (2006) identify four political economies, of which the neo-liberal model, exemplified by the US but including other Anglo-Saxon countries such as Australia, ${ }^{3}$ New Zealand and England and Wales, is most associated with high imprisonment rates. Lacey $(2008,2011)$ identifies two main models: liberal market economies and co-ordinated market economies. She contrasts them in the broader context of their political and economical institutions and legal and constitutional structures, as well as their relationship with the bureaucracy and judiciary, and with the media and public opinion. On each of these levels, the characteristics of a liberal market 
economy make them more vulnerable to punitiveness, penal populism and exclusion. Building on their earlier work, Cavadino and Dignan (2011) explore reasons for the relationship between neo-liberalism and punitiveness. They see as the main explanations the political culture and the interaction with political and state institutions that derive from the different political economies, as well as the impact of public opinion and the media within these political economies, which shape punishment. In doing so, they consider Lacey's (2008) emphasis on the political institutions' susceptibility to penal populism in the neo-liberal political economy as too limited. In regard to the association between neo-liberalism and punitiveness, exceptions are also found and, again, it is Downes (2011) who brings this up with regard to Canada.

Canada as a case study

Commenting on the Cavadino and Dignan model (2006), Webster and Doob (2011) point to the fact that Canada - while not included in their analysis - would most probably have been categorised alongside the Anglo-Saxon neo-liberal countries (with the US, England and Wales, Australia, New Zealand and South Africa), although the Canadian imprisonment rate has been stable and a lot lower than in the other countries belonging to this group, fluctuating around 100 out of 100,000 adults (Webster and Doob 2007). Actually, based on their imprisonment rate, Canada would be closer to the conservative corporatist countries (such as Italy, Germany, France, the Netherlands). On various occasions Doob and Webster have criticised the fact that Canada is too easily thrown in the same basket as the other Anglo-Saxon countries with which they have a common historical and institutional heritage, and that criminologists have been mainly looking at change, ignoring the interesting example of Canadian stability in the prison population for over about 50 years (Doob and Webster 2006; Webster and Doob 2007, 2011).

Along the same lines, Meyer and O'Malley (2005) test Garlands' thesis of a lurch towards punitiveness after a golden age of rehabilitation in the Canadian context. They explain that, in Canada, there never was one set ideology as, when rehabilitation was the leading policy in the US in the sixties and seventies, it was only one of the official Canadian policy directions, together with protection, retribution and deterrence, all being parts of a policy with an emphasis on the protection of the society. At that time, the Canadian imprisonment rate was one of the highest of the world, higher than the US, and a large proportion of prisoners was being held in maximum security conditions. When rehabilitation lost is credibility in the seventies, which is well documented in the 'Nothing works' and 'Justice' literatures, this heralded the increase in American prison numbers, while the opposite happened in Canada: rehabilitation became a more important goal of corrections and imprisonment rates started to go down, as did the number of prisoners in maximum security conditions. As such, there was no distinctive punitive turn in the Canadian penal landscape, but a newly struck balance between punishment and rehabilitation, which is still around now and which could, according to these authors, be described as uniquely Canadian, dissociating them from the US model.

Webster and Doob (2007) also point to differences between the US and Canada. Besides some historical, structural and political characteristics, which protect Canada from punitiveness and populist reactions, there are also cultural differences. Public opinion in Canada doesn't have the moral taste for harsh punishment and politicians don't believe in it. Further, Canadians want to be seen as different from the US and research reveals that they are fundamentally different from Americans, adhering to different values and beliefs. Interesting is the fact that these value structures seem to correlate with imprisonment rates: in the US states where the value system was most 'Canadian-like', the imprisonment rates were lower than in other states (Doob ad Webster 2006; Webster and Doob 2007).

Returning to the neo-liberal explanatory model, according to Webster and Doob (2011), penality is more complex than the political economy that Cavadino and Dignan (2006) describe; simple political or economical models are insufficient as an explanatory framework. As both Cavadino and Dignan (2006) and Lacey (2008) are focussing on a limited number of theoretically relevant factors, the explanatory power of their approach is incomplete. Webster 
and Doob (2011) conclude that it is not only the number of factors that is fundamental but also the conceptual approach to the analysis of these (multiple) factors. It is particularly the interaction between these structural, cultural, historical and institutional features that explains Canadian penality. The same characteristics in another context might result in a different penal reality. The latter might be happening in Canada at this very moment, as the political climate seems to have hardened towards a more punitive discourse and the prison population has been going up since 2006 (Webster and Doob 2007, 2011).

\section{Conclusion}

According to this case study, it seems that Brown (2011) is right in warning against overstating the role of neo-liberalism in explaining punitiveness. The relationship between both seems to be looser and indirect. It depends on the form of neo-liberalism that is adopted and imposed (Karstedt 2012, 2013). This is confirmed in the analysis of O'Malley (2002), where he compares neo-liberalism in the US and Australia. Neo-liberalism in the US is more entangled with conservatism, while in Australia it is rooted in a more socio-democratic tradition, and welfare models can remain intact in the latter. According to Brown (2013) imprisonment rates might have more to do with race and colonialism/post-colonialism than with neo-liberalism, as most neo-liberal political economies are also former colonial or post-colonial countries (US, UK, South Africa, Australia, New Zealand). Indeed, while the imprisonment rate of these so-called settler societies is not necessarily high per se (cf. Canada), they all suffer from an over-representation of Indigenous people in their criminal justice system, which might also explain remarkable intra-national differences in their imprisonment rates. In the remainder of the article, I move on from the global and the national, to zoom in on intra-national differences and the possible relation with Indigenous over-representation in the criminal justice system.

\section{Local variances and Indigenous ${ }^{4}$ over-representation}

In Australia, as in other federal states with a comparable first nation, such as Canada, the imprisonment rates are highest in the jurisdictions with large Indigenous populations (Australia has six states and two territories, all having their own criminal justice jurisdiction). Therefore, as Blagg (2008) argues, it might not be possible to apply one and the same explanatory model on settler societies; they are not one society, as there remains a social and cultural bifurcation between the colonised and the coloniser. In the following paragraphs I analyse the colonisation thesis and see to what extent it holds against other explanations for Indigenous overrepresentation in both countries.

\section{The impact of colonialism on contemporary penal practice}

Australia carries a sad record of maltreatment of its first nation people: a record of dispossession, discrimination that affected various aspects of life, resulting in an 'apartheids regime' in Australia, exemplified by the forced removal of Indigenous children from their families (cf. the stolen generation) (Cunneen 1999; Hogg 2001). Looking at the impact of colonisation on the penal complex, most material in this respect is available from two 'frontier' states, Western Australia and Queensland. Western Australia was the only state to develop a separate penal system for Indigenous offenders (cf. Rottnest Island and 'native cells'; and 'compounds' in other prisons), where the dislocation from their land and community contributed to the harsh penal regime (Finnane and McGuire 2001; Hogg 2001;). Queensland is the main example of segregation of Aboriginal people in reserves, missions and stations. They were introduced under the banner of the 'protection' of Indigenous people and, while administrative in nature, Indigenous people there were subjected to similar disciplinary regimes and punishment as was the case in penal institutions. Further, this protective measure could be imposed following a term of imprisonment or even without a formal conviction; it sometimes included deportation (for example, to Palm Island) and could be of an indefinite period of time, leading to segregation and extended supervision (Finnane and McGuire 2001; Finnane and Richards 2010). When eventually Indigenous people gained access to full 
citizenship in the sixties, the number and proportion of Indigenous people in the prison started to rise (Broadhurst 1987; Finnane and McGuire 2001; Finnane and Richards 2010; Hogg 2001; Purdy 1996). It is, however, very difficult to assess what the exact relationship is between colonist practices and over-representation of Indigenous people in the criminal justice system. Firstly, in most jurisdictions systematic data on race and ethnicity are lacking from the early collections. ${ }^{5}$ Further, the end of the protection era coincided with other factors such as shrinking economic opportunities and rising unemployment. Finally, there were the unintended effects of emancipation: the equal wages legislation, which resulted in many Indigenous stockmen losing their jobs and homes, causing them to migrate to country towns; and the removal of alcohol bans, allowing them full access to drinking, with all the known consequences (Broadhurst 1987; Hogg 2001).

The over-representation and social disadvantage of Indigenous people in Canada are also linked to the colonial heritage and the abuses that came with it. Over time, several commissions have looked into this issue and documented the Canadian colonial history, with similar situations to those reported for Australia. Pursuing a comparable assimilation policy, the process included relocation of Aboriginal people, disturbance of their traditional economic balance, criminalisation of their rituals, restrictions on fundamental rights and liberties, and the development of a residential school system where the Aboriginal identity of the children was denied and destroyed. According to these reports, the experience of colonialism best explains the over-representation of Aboriginal people in the criminal justice system. A report by the Canadian Criminal Justice Association states that historical factors, combined with present socio-economic conditions, produce offending behaviours that reflect social - rather than criminal - problems in Aboriginal communities (Canadian Criminal Justice Association 2000; Royal Commission on Aboriginal Peoples 1995). I examine the possible impact of colonisation on Indigenous over-representation in both countries in two further case studies.

\section{Indigenous over-representation in Australia}

According to the 2011 national population census, Indigenous people make up about 2.5 per cent of the total Australian population (548,370 people identified as being of Aboriginal and/or Torres Strait Islander origin). While the highest proportions of the total Australian Indigenous population live in New South Wales (31.5 per cent) and Queensland (28.4 per cent), their percentage as part of the general state population is by far the highest in the Northern Territory (26.8 per cent). They represent only 4 per cent or less of the population in each of the other Australian jurisdictions (Australian Bureau of Statistics 2012). On 30 June 2012, Indigenous people comprised 27 per cent of the total prisoner population. The Indigenous age standardised imprisonment rate $(1,914$ per 100,000 adult population) was 15 times higher than for nonIndigenous people $(129$ per 100,000) (Australian Bureau of Statistics 2013b). The proportion of Indigenous people in the prisoner population is the highest in the Northern Territory (83.8 per cent), followed by Western Australia (39.7 per cent) and Queensland (29.7 per cent), all above the national average of 27.2 per cent. Based on daily averages, the over-representation of Indigenous people in the prison population is most significant in Western Australia, with an imprisonment rate of 4,059 per 100,000 adult persons, followed by the Northern Territory $(2,951)$ and South Australia $(2,620)$ (Australian Bureau of Statistics 2013a).

The issue of the over-representation of Indigenous people in the Australian criminal justice system became a matter of debate after the Royal Commission into Aboriginal Deaths in Custody (RCIADIC). In 1991 RCIADIC reached the conclusion that the over-representation of Indigenous people in prison was the main reason for the high number of deaths in custody. According to them, this resulted from a combination of (1) a bias in the operation of the criminal justice system; and (2) economic and social disadvantage. They issued a number of recommendations to reduce the imprisonment rates of Indigenous people. Initiatives were taken at the Commonwealth level to address Indigenous social and economic disadvantage and 
to reduce sources of discrimination against Indigenous people in the criminal justice system. At the state and territory jurisdiction levels, there are several examples of legislation that was seen as discriminatory against socially and economically disadvantaged groups being revoked (for example, decriminalisation of public drunkenness) and also legislation enacted to ensure incarceration would be used as a sanction of last resort (Snowball and Weatherburn 2006). Yet it is widely acknowledged that, in terms of achieving a reduction of Indigenous imprisonment rates, these reforms have met with remarkably little success. Indeed, as the Indigenous imprisonment rate in 1991 was 13 times higher than the non-Indigenous rate, and in 2012 was 15 times higher, the situation has even worsened.

In addition to the government initiatives, much scholarly attention has been devoted to the reasons for the over-representation of Indigenous people in Australian prison populations. Two main sets of explanations dominate the research in this field: the first postulates that the overrepresentation of Indigenous people emanates from higher relative rates of Indigenous (re)offending; while the second asserts the existence of 'institutional racism' or 'systemic bias' 6 throughout the criminal justice system, disadvantaging Indigenous people and so contributing to their over-representation in the prison population. I summarise the main evidence for both arguments.

\section{Different involvement in crime}

Weatherburn and Holmes (2010) sum up what has been uncovered by research since RCIADIC. Based on analyses of the Australian Bureau of Statistics data, they demonstrate that causes of Indigenous over-representation are (1) a higher rate of arrest for serious offences amongst Indigenous people; (2) a higher likelihood of bail refusal amongst those arrested; and (3) a higher likelihood of imprisonment amongst those convicted. These factors can be explained, it is argued, by the over-representation of Indigenous persons amongst those who commit / are charged with serious criminal offences, which in turn can be related to disadvantage. However, as disadvantage also covers a lot of areas that are not necessarily criminogenic, Weatherburn and Holmes wanted to find out what the specific factors are that account for the overrepresentation of Indigenous offenders. Based on various sources, these researchers demonstrated that Indigenous Australians generally score worse than non-Indigenous Australians on four critical factors representing key risks for involvement, frequency and seriousness of offending. These factors are: (1) child neglect and abuse; (2) drug and alcohol abuse; (3) poor school performance and early school leaving; and (4) unemployment. According to these authors, the economic and social disadvantage as mentioned by the RCIADIC is more likely to be a result of these four factors, instead of the cause of them.

\section{Bias throughout the criminal justice processing}

While there are numerous accounts of evidence that, historically, Indigenous people have been subject to discriminatory treatment throughout the criminal justice system, the question remains as to whether this is still the case. The topic of a possible bias has been investigated at the different stages of the criminal justice system.

Systemic biases in the law: Legislative measures, however not intentionally racial, might have different effects on Indigenous and non-Indigenous people. Examples of racism enshrined in law are public order offences (like public drunkenness) affecting Aboriginal people disproportionately due to the public nature of Aboriginal life (Broadhurst 1987; Cunneen 2001). Further, mandatory sentencing laws, which exist in Western Australia and the Northern Territory, are most likely to affect Indigenous people convicted for trivial offences (Broadhurst 1997; Hogg 2001). More recently, there was the introduction of the Prohibited Behaviour Orders in Western Australia in 2010 which, at several levels, increase the risk of Indigenous people becoming the subject of it and entering the criminal justice system through a civil order (Crofts and Mitchell 2011). 
Racist Policing: Racial discrimination claims are strongest at the police level: Cunneen (2001) describes the role of police during the colonial period and claims that there are continuities with contemporary policing. As police officers are the main gatekeepers to the criminal justice system, their discretionary powers can have an enormous impact on the following stages, and evidence shows us that, in regards to Indigenous offending, the more punitive options are chosen. There is, indeed, some evidence of Indigenous juvenile offenders being less diverted (Snowball 2008), and Indigenous people being less likely to be granted bail (Weatherburn and Snowball 2012). Cunneen does admit that the discretionary impact is greatest upon less serious charges which do not generally carry prison sentences. However, he argues, the eventual sentencing outcomes might as well be the result of an 'accumulation of disadvantages' based on the social construct that the criminalisation process is, starting with the police force. For Cunneen, it is the ongoing criminogenic effects of colonialisation that form the basis of Indigenous over-representation.

The operation of the court and judicial system: There are various recent studies available that compare Indigenous and Non-Indigenous sentencing outcomes. An important methodological concern here is to ensure that apples are being comparing with apples - sentence disparity does not necessarily imply racism or discrimination - which means that the sentencing outcomes have to be controlled for other factors that might influence the decision making process. Controlling for other sentencing factors, Snowball and Weatherburn (2006) found no evidence of racial bias in sentencing in the New South Wales courts, the higher imprisonment rate being explained by (1) a higher rate of violent crime; and (2) a higher rate of re-offending / breach of non-custodial sentences. Building on this study while refining the methodology, Snowball and Weatherburn (2007) found that the initially big baseline difference between imprisonment for Indigenous and non-Indigenous people shrinks to less than one per cent after controlling for relevant sentencing variables. Actually, they assert that courts in New South Wales place less weight on a long criminal career when dealing with Indigenous offenders than in the case of non-Indigenous offenders so, they conclude, the over-representation of Indigenous offenders in the prison has little to do with judicial racism (Snowball and Weatherburn 2007).

Jeffries and Bond (2009) have tested the hypothesis of Indigenous sentencing differences in various Australian states, using techniques that allow for control for other variables. They came to a number of conclusions. In South Australia's higher courts, the findings are contradictory to those of Snowball and Weatherburn $(2006,2007)$ above in that Indigenous offenders were less likely to be sentenced to terms of imprisonment but, when they did receive prison sentences, they tended to be for longer periods than was the case for non-Indigenous offenders ${ }^{7}$ (Jeffries and Bond 2009). However, this effect disappeared when studying the situation in Western Australian higher courts: Indigenous status did not show any direct effect on the decision to imprison after controlling for other sentencing factors (Bond and Jeffries 2011). In Queensland, where both the higher and the lower courts were studied, the effect disappeared in the higher courts while, in the lower courts Indigenous, people had an increased risk of receiving prison sentences, where all other control variables were equal (Bond and Jeffries 2012).

These differences between states in sentencing outcomes for Indigenous people in lower courts were confirmed in later research checking for the sentence length; however, the effect varied according to the state. In South Australia Indigenous people received shorter sentences than non-Indigenous people; in New South Wales there was hardly any difference; while in Western Australia the sentence length for Indigenous offenders was longer (Jeffries and Bond 2011 in Sentencing Advisory Council 2013; Bond, Jeffries and Weatherburn 2011). Again, the diverse findings make no allowance for a systematic bias in sentencing. 


\section{Aboriginal over-representation in Canada}

Up until the 1960s, Aboriginal people were under-represented in Canadian federal prisons, and the growing over-representation was only revealed in 1975. According to a recently released report from the Office of the Correctional Investigator, Aboriginal offenders currently represent 21 per cent of the federal Canadian prison population, although they compose only 4 per cent of the national population. Over the past decade (2001-2011), there was a nearly 40 per cent increase of Aboriginal people in the prison, and this over-representation is even greater in certain regions and provincial institutions. Canada consists of ten provinces and three territories, the territories being scarcely populated and with large Aboriginal populations. Imprisonment rates are high in these territories and two of the provinces, also with a significant Aboriginal population (Manitoba and Saskatchewan) (Webster and Doob, 2011). As the Aboriginal population is younger and growing much faster than the Canadian population, the expectation is that Aboriginal over-representation will rise even further in the future. The report of the Office of the Correctional Investigator found that there had been major failures in the Correctional Service of Canada's efforts to make the systemic policy and resource changes, required by law, to reduce Aboriginal over-representation in federal penitentiaries (Office of the Correctional Investigator 2012).

In Canada, as in Australia, a variety of explanations have been proposed for the overrepresentation of Aboriginal people in prison populations. Roberts and Doob (1997) provide an overview of the main findings in this respect. They point out that discriminatory treatment of Aboriginal and black people accounts, in part at least, for the over-representation. This discrimination has been described in various stages of the criminal justice process. A summary of the main findings are that: the relation between Aboriginals and police are often hostile, increasing the likelihood of conflict and high arrest rates, while at the same time police officers are often called in for problems that are not strictly police business because they are the only 'service' available; sentencing options are limited in remote areas and may result in a choice between imprisonment or nothing; there is failure of Indigenous offenders to pay fines; and, finally, there are apparently lower rates of parole by provincial parole boards. However, Roberts and Doob (1997) acknowledge that discriminatory treatment is not explaining everything and that some data suggest that, for certain offences, Aboriginal people get even shorter sentences than non-Aboriginals. The authors conclude that Canadian Aboriginal people suffer from multiple forms of social and economic disadvantage (including unemployment, substance abuse). This disadvantage, together with higher rates of crime and/or police attention and evidence of discrimination, particularly at police level but also in sentencing and early release, are the causes of the high rates of Indigenous imprisonment.

\section{Conclusion}

The parallels between the situation of first nations people in Canada and Australia are striking. In both cases the problems are rather recent and coincide with the dismantling of some major characteristics of colonialism. In both cases, the causes are being sought in an inextricable cluster of multiple forms of deprivation and discrimination, leading to Indigenous people forming a minority within the dominant society (Blagg 2008). This brings us back to the writings of Loic Wacquant (2009), who describes the over-representation of black Americans in US prisons in terms of hyper-incarceration. He refers to the 'extra penological' functions of the prison system, which he views as a substitute for the earlier ghettos, with both factors serving to neutralise a part of the population that is considered a risk to society. ${ }^{8}$ Once the walls of the ghetto started to crack throughout the 1970s, the walls of the prison were expanded. This leads us to the question as to whether penal captivity is an intended, if covert, mechanism for keeping a definite group separate and preventing their assimilation into society. For now, I conclude- as the overview above shows - that institutional racism or a systematic bias are difficult to demonstrate; however, there seems to be no doubt that there is an indirect relationship in a way that colonialism created the conditions for multiple forms of deprivation, leading to 
criminalisation. In that situation the question of to what extend treating 'unequals equally' is discriminatory in its own right arises.

\section{The future of comparative research}

This argument as presented has moved from the global to the national and further to the local. It is clear that global explanatory models, while leading the way, can never capture the complexity of local situations. To understand the trajectories described above, especially the ones deviating from the master narratives which are now well documented in various studies, I argue there is the need to broaden the lens and investigate factors other than the 'usual suspects'. Behind the more tangible global models of political structures and economic models exist fundamental values and cultural norms, rooted in local historical backgrounds. In more recent research investigating anomalies and unexpected changes, an increasing emphasis on the importance of the national, local, and regional dynamics has become apparent. As was demonstrated in this article, global forces can affect nation states in very different ways and, even beyond that, there is a need for further examination so as to understand and be able to explain intra-national differences. This seems to be particularly the case for Settler States, where the penal culture is strongly influenced by the strength of their colonial heritage and the presence of Indigenous people. Investigating all these layers of explanatory factors, as well as their interaction, promises to be a fruitful future for comparative criminology.

Correspondence: Dr Hilde Tubex, ARC Future Fellow, Crime Research Centre, University of Western Australia, Crawley, WA, 6009. Email: hilde.tubex@uwa.edu.au

\footnotetext{
${ }^{1}$ Dr Hilde Tubex is the recipient of an Australian Research Council Future Fellowship (project number FT100100627).

2 The number of prisoners per 100,000 inhabitants. For a discussion regarding the advantages and disadvantages of using imprisonment rates as a proxy for punitiveness, see Tubex 2013.

3 They do, however, acknowledge that there are also traces of 'social democracy' in Australia.

${ }^{4} \mathrm{We}$ are following the terminology used in the literature consulted; for Australia the term Indigenous is most frequently used, while the Canadian literature mainly refers to Aboriginal people.

${ }^{5}$ It was as late as 1967 that Aboriginal people were included in the national census; therefore, systematic and reliable data are hard to find for the preceding period.

${ }^{6}$ For a discussion on these terms, see Cunneen 2006.

${ }^{7}$ For the possible reasons for indigeneity as a mitigating factor, see Jeffries and Bond 2010.

${ }^{8} \mathrm{He}$ expands this analysis to the over-representation of foreigners in European prisons as a result of their offending behaviour stemming from their situation of multiple deprivations, the targeting by police and differential processing in the courts (Wacquant 2006).
}

\section{References}

Australian Bureau of Statistics (2012) 2075.0 - Census of Population and Housing: Counts of Aboriginal and Torres Strait Islander Australians 2011. Available at http://www.abs.gov.au/ausstats/abs@.nsf/mf/2075.0 (accessed 2 September 2013).

Australian Bureau of Statistics (2013a) 4512.0 - Corrective Services, Australia, March Quarter 2013. Available at http://www.abs.gov.au/ausstats/abs@.nsf/mf/4512.0 (accessed 2 September 2013).

Australian Bureau of Statistics (2013b) 4517.0 - Prisoners in Australia, 2012. Quality Declaration. Available at http://www.abs.gov.au/ausstats/abs@.nsf/mf/4517.0/ (accessed 2 September 2013). 
Baker E and Roberts JV (2005) Globalization and the new punitiveness. In Pratt J, Brown D, Brown M, Hallsworth S and Morrison W (eds) The New Punitiveness: Trends, Theories, Perspectives. London: Willan Publishing: 121-138.

Becket K and Western B (2001) Governing social marginality: Welfare, incarceration and the transformation of state policy. Punishment \& Society 3(1): 43-59.

Blagg H (2008) Crime, Aboriginality and the Decolonisation of Justice. Sydney: Hawkins Press.

Boone M and Moerings M (2007) Growing prison rates. In Boone M and Moerings M (eds) Dutch Prisons. The Hague: Boom Juridische uitgevers: 51-77.

Boone M and van Swaaningen R (2012) Dalende detentiecijfers in Nederland: Strafwerk voor Gerard de Jonge? In Claessen J and de Vocht D (eds) Humaan strafwerk: Liber Amicorum Gerard de Jonge. Nijmegen: Wolf Legal Publishers: 51-71.

Bond C and Jeffries S (2011) Indigeneity and the judicial decision to imprison. British Journal of Criminology 51: 256-277.

Bond C and Jeffries S (2012) Indigeneity and the likelihood of imprisonment in Queensland's adults and children's courts. Psychiatry, Psychology and Law 19(2): 169-183.

Bond C Jeffries S and Weatherburn D (2011) How much time? Indigenous status and the sentenced imprisonment term in New South Wales. Australia and New Zealand Journal of Criminology 44(2): 272-290.

Broadhurst R (1987) The imprisonment of the Aborigine in Western Australia: 1957-1987. In Hazelhurst K (ed) Ivory Scales: Black Australians and the Law. Sydney: University of New South Wales Press: 153-189.

Broadhurst R (1997) Aborigines and crime in Australia. In Tonry M (ed) Crime and Justice: A Review of Research, Volume 21. Chicago: University of Chicago Press: 407-468.

Brown D (2011) Neoliberalism as a criminological subject. Australian \& New Zealand Journal of Criminology 44(1): 129-142.

Brown D (2013) Prison rates, social democracy, neoliberalism and justice reinvestment. In Carrington K, Ball M, O’Brien E and Tauri JM (eds) Crime, Justice and Social Democracy. International Perspectives. London: MacMillan: 70-85.

Canadian Criminal Justice Association (2000) Aboriginal Peoples and the Criminal Justice System. Ottawa.

Cavadino M and Dignan J (with others) (2006) Penal Systems: A Comparative Approach. London: Sage Publications.

Cavadino M and Dignan J (2011) Penal comparisons: Puzzling situations. In Crawford A (ed) International and Comparative Criminal Justice and Urban Governance. Cambridge: Cambridge University Press: 193-213.

Crofts T and Mitchell T (2011) Prohibited behaviour orders and Indigenous overrepresentation in the criminal justice system. Current Issues in Criminal Justice 23 (2): 277-285.

Cunneen C (1999) Criminology, genocide and the forced removal of Indigenous children from their families. Australian and New Zealand Journal of Criminology 32(2): 124-138.

Cunneen C (2001) Conflict, Politics and Crime: Aboriginal Communities and the Police. Sydney: Allen and Unwin.

Cunneen C (2006) Racism, discrimination and the over-representation of Indigenous people in the criminal justice system: Some conceptual and explanatory issues. Current Issues in Crime and Justice 17(3): 329-347.

Doob AN and Webster C (2006) Countering punitiveness: Understanding stability in Canada's imprisonment rate. Law \& Society Review 40(2): 325-367.

Downes D (2011) Comparative criminology, globalization and the 'punitive turn'. In Nelken D (ed) Comparative Criminal Justice and Globalization. Farnham: Ashgate: 27-47. 
Downes D and Hansen K (2006) Welfare and punishment in comparative perspective. In Armstrong S and McAra L (eds) Perspectives on Punishment: The Contours of Control. Oxford, New York: Oxford University Press: 133-154.

Finnane M and McGuire J (2001) The uses of punishment and exile: Aborigines in colonial Australia. Punishment \& Society 3(2): 279-298.

Finnane M and Richards J (2010) Aboriginal violence and state response: Histories, policies and legacies in Queensland 1860-1940. Australian \& New Zealand Journal of Criminology 43(2): 238-262.

Garland D (2001) The Culture of Control: Crime and Social Order in Contemporary Society. Oxford, New York: Oxford University Press.

Hogg R (2001) Penality and modes of regulating Indigenous peoples in Australia. Punishment \& Society 3(3): 355-379.

Jeffries S and Bond C (2009) Does indigeneity matter? Sentencing Indigenous offenders in South Australia's higher courts. Australian and New Zealand Journal of Criminology 42(1): 47-71.

Jeffries S and Bond C (2010) Narratives of mitigation: Sentencing Indigenous criminal defendants in South Australia's higher courts. Journal of Sociology, 46(3): 219-237.

Karstedt S (2012) Crime. In Ritzer G (ed) The Wiley-Blackwell Encyclopedia of Globalization, Volume 1. Oxford: Blackwell: 342-352.

Karstedt S (2013) Never waste a good crisis. ESC Newsletter 12(1): 5-12.

Lacey N (2008) The Prisoners' Dilemma: Political Economy and Punishment in Contemporary Democracies. Cambridge: Cambridge University Press.

Lacey N (2011) Why globalisation doesn't spell convergence: Models of institutional variation and the comparative political economy of punishment. In Crawford A (ed) International and Comparative Criminal Justice and Urban Governance. Cambridge: Cambridge University Press: 193-213.

Meyer J and O'Malley P (2005) Missing the punitive turn? Canadian criminal justice, 'balance' and penal modernism. In Pratt J Brown D and Brown M (eds) The New Punitiveness: Trends, Theories, Perspectives. Cullompton: Willan: 201-217.

Nelken D (2011) Making sense of punitiveness: The 2008 Wiarda inaugural lecture. In Nelken D (ed) Comparative Criminal Justice and Globalization. Farnham: Ashgate: 11-25.

Office of the Correctional Investigator (2012) Spirit matters: Aboriginal people and the corrections and conditional release act. Available at http://www.oci-bec.gc.ca/cnt/rpt/othaut/oth-aut20121022-eng.aspx (accessed 2 September 2013).

O'Malley P (2002) Globalizing risk? Distinguishing styles of 'neo-liberal' criminal justice in Australia and the USA. Criminology and Criminal Justice 2(2): 205-222.

Purdy J (1996) Postcolonialism: The emperor's new clothes? Social \& Legal Studies 5(3): 405426.

Roberts J and Doob A (1997) Race, ethnicity, and criminal justice in Canada. In Tonry M (ed) Crime and Justice: A Review of Research, Volume 21. Chicago: University of Chicago Press: 469522.

Royal Commission on Aboriginal Peoples (1995) Bridging the Cultural Divide. Ottawa: Canada Communications Group.

Savelsberg J (2011) Globalisation and states of punishment. In Nelken D (ed), Comparative Criminal Justice and Globalization. Farnham: Ashgate: 69-86.

Sentencing Advisory Council (2013) Comparing sentencing outcomes for Koori and non-Koori adult offenders in the Magistrates' Court of Victoria. Available at https://sentencingcouncil.vic.gov.au/content/publications/comparing-sentencingoutcomes-koori-and-non-koori-adult-offenders (accessed 2 September 2013). 
Snowball L (2008) Diversion of Indigenous juvenile offenders. Trends \& Issues in Crime and Criminal Justice, Number 355. Canberra: Australian Institute of Criminology.

Snowball L and Weatherburn D (2006) Indigenous over-representation in prison: The role of offender characteristics. Crime and Justice Bulletin, Number 99. Available at http://www.lawlink.nsw.gov.au/lawlink/bocsar/ll_bocsar.nsf/pages/bocsar_pub_cjb (accessed 2 September 2013).

Snowball L and Weatherburn D (2007) Does racial bias in sentencing contribute to Indigenous overrepresentation in prison? Australian and New Zealand Journal of Criminology 40(3): 272 290.

Tubex H (2013) Pitfalls of comparative (penological) research and how to overcome them. In Beyens K, Christiaens J, Claes B, De Ridder S, Tournel H and Tubex H (eds) The Pains of Doing Criminological Research. Brussels: VUBPress: 195-215.

van Dijk J (2011) Trends in Dutch prisoner rates: Regression to the mean or enduring exception? In Kury H and Shea E (eds) Punitivity International Developments, Volume 1: Punitiveness - a Global Phenomenon? Bochum: Universitätsverlag Dr. Brokmeyer: 203-225.

van Swaaningen R (2013) Reversing the punitive turn: The case of the Netherlands. In Daems T, Snacken S and Van Zyl Smith D (eds) European penology? Oxford: Hart Publishing: 339-360.

Vollaard B and Moolenaar D (2009) Beperkte invloed rechter op gebruik celstraf, Nederlands Juristenblad - 15052009 - Afl 19: 1208-1215.

Vollaard B, Versteegh P and Brakel J van (2009) Veelbelovende verklaringen voor de daling van de criminaliteit na 2002. Apeldoorn: Politie \& Wetenschap.

Wacquant L (2006) Penalization, depoliticization, racialization: On the over-incarceration of immigrants in the European Union. In Armstrong S and McAra L (eds) Perspectives on Punishment: The Contours of Control. Oxford, New York: Oxford University Press: 83-100.

Wacquant L (2009) Punishing the Poor: The Neoliberal Government of Social Insecurity. Durham: Duke University Press.

Weatherburn D and Holmes J (2010) Re-thinking indigenous over-representation in prison. Australian Journal of Social Issues 45(4): 559-576.

Weatherburn D and Snowball L (2012) The effect of Indigenous status on the risk of bail refusal. Criminal Law Journal 36(1): 50-57.

Webster CM and Doob AN (2007) Punitive trends and stable imprisonment rates in Canada. In Tonry M (ed) Crime, Punishment and Politics in Comparative Perspective. Crime and Justice: A Review of Research, Volume 36. Chicago: University of Chicago Press: 279-369.

Webster CM and Doob AN (2011) Explaining Canada's imprisonment rate: the inadequacy of simple explanations. In Crawford A (ed) International and Comparative Criminal Justice and Urban Governance. Cambridge: Cambridge University Press: 304-330. 